\title{
DA PRISÃO POR DÍVIDA ALIMENTAR E O PACTO SAN JOSÉ DA COSTA RICA
}

\author{
IMPRISONMENT FOR NONCOMPLIANCE WITH CHILD SUPPORT ORDER AND THE \\ PACT OF SAN JOSE, COSTA RICA
}

\section{Guilherme Domingos de Luca* Laura Bazotte Borges**}

\begin{abstract}
RESUMO: O presente estudo, inserido na linha de pesquisa "Fundamentos dogmáticos da experiência Jurídica", visa a analisar o instituto da "Prisão civil por dívida alimentar na relação de parentesco em face do impacto gerado pelo Pacto de San José da Costa Rica", sob enfoque da aplicação do instituto dos alimentos na relação de parentesco. Em razão das controvérsias, será estudado o status normativo ao qual o Pacto foi elevado no ordenamento jurídico brasileiro, em decorrência da promulgação da Emenda Constitucional $\mathrm{n}^{\mathrm{0}} 45 / 2004$. A pesquisa foi pautada na análise de doutrinas, em especial das obras de direito de família, buscando apontar o status normativo do Pacto, visto que este tratado prevê a prisão civil do inadimplente da obrigação alimentar, após a promulgação da Emenda Constitucional $\mathrm{n}^{\circ}$ 45/2004. Trata-se da metodologia dedutiva, que levou em consideração as comparações bibliográficas, para se concluir qual a real importância desta norma internacional no direito positivo vigente.
\end{abstract}

PALAVRAS-CHAVE: Alimentos. Prisão Civil. Pacto de São José da Costa Rica.
ABSTRACT: This study aims to analyze the institute of "civil imprisonment for noncompliance with child support order in face of the impact generated by the Pact of San José, Costa Rica". Because of the controversy, the legal status of this Pact in the Brazilian legal system and the implications of the enactment of Constitutional Amendment 45/2004 will be studied. The research was based on the analysis of opinions from legal theorists, especially in the family law field, seeking to identify the legal status of the Pact, since this treaty enables the imprisonment for noncompliance with child support order and was enacted after the Constitutional Amendment 45/2004, which forbids civil imprisonment. Through a deductive methodology, which took into account comparative literature, this research will help to dimension the real importance of this Pact in the current positive law.

KEYWORDS: Child Support. Civil Imprisonment. Pact of San Jose, Costa Rica.

SUMÁRIO: Introdução. 1 Origem e Conceituação. 2 Condições para se Decretar a Prisão Civil. 3 Ingresso dos Tratados no Ordenamento Jurídico Brasileiro. 4 Controvérsias do Status Jurídico da Prisão Civil. 5 Da Análise Jurisprudencial. Considerações Finais. Referências.

\section{INTRODUÇÃO}

O ser humano, desde a concepção, tem como primeiro direito fundamental, o direito à sobrevivência. Entretanto, para que ele possa sobreviver com dignidade, são necessários meios materiais e afetivos, entre os quais estão os alimentos.

O principal fundamento da obrigação de prestar alimentos está baseado nos princípios da dignidade da pessoa humana e da solidariedade familiar, bem como o "maior interesse da criança", já que a obrigação alimentar se trata de um direito personalíssimo, devido pelo alimentante ao alimentando, em razão da relação de parentesco que liga um ao outro.

\footnotetext{
* Mestre em Teoria do Direito e do Estado pelo Centro Universitário Eurípedes de Marília (UNIVEM), São Paulo. Especialista em Direito do Trabalho e Previdenciário pela Pontifícia Universidade Católica de Minas Gerais. Bolsista CAPES/PROSUP.

** Especialista em Direito do Trabalho e Previdenciário pelo Centro Universitário Eurípedes de Marília (UNIVEM), São Paulo.
} 


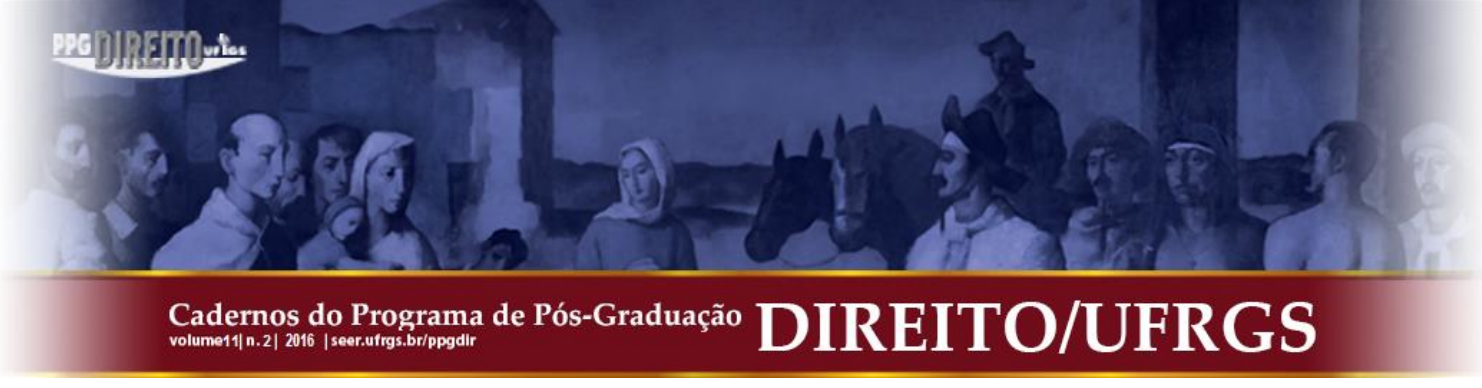

Assim, para a fixação dos alimentos, é oportuno observar o binômio necessidade versus possibilidade, ou seja, a necessidade de quem pleiteia e a possibilidade da pessoa obrigada a prestar alimentos.

$\mathrm{Na}$ relação de parentesco, os alimentos são recíprocos entre pais e filhos e extensivos a todos os ascendentes, recaindo a obrigação nos mais próximos em grau, uns em falta de outros. Além disso, na falta dos ascendestes, a obrigação alimentar recai aos descendentes observadas a ordem de sucessão e, na falta deles, aos irmãos germanos ou unilaterais.

No entanto, caso a pessoa que deve prestar alimentos não cumpra com sua obrigação, será necessária a propositura de uma ação de alimentos, visando a compelir o devedor a adimplir a obrigação alimentar.

Uma vez proferida a sentença na ação de alimentos, ela poderá ser executada de várias formas, dentre as quais se destaca a execução prevista no artigo 733 do Código de Processo Civil e artigo 19 da Lei n. ${ }^{\circ}$ 5.478/68, isto é, através da prisão civil do devedor de alimentos. O débito alimentar que autoriza a prisão civil do alimentante é o que compreende as três prestações anteriores ao ajuizamento da execução, incluindo as que se vencerem no curso do processo, conforme dispõe a Súmula 309 do Superior Tribunal de Justiça.

Assim, através do presente estudo, busca-se demonstrar o status normativo ao qual o Pacto de San José da Costa Rica foi elevado, no ordenamento jurídico brasileiro, visto que o referido tratado prevê expressamente a prisão civil do inadimplente da obrigação alimentar, após a promulgação da Emenda Constitucional nº 45/2004.

\section{ORIGEM E CONCEITUAÇÃO}

Após o término da Segunda Guerra Mundial, frente às atrocidades cometidas, a comunidade internacional percebeu a necessidade de reiterar o reconhecimento dos direitos fundamentais da pessoa humana, criando, assim, uma nova ordem internacional para proteção aos direitos fundamentais, a qual foi aceita por vários Estados, como consenso geral de alicerce da estabilidade social e da paz mundial (VALENTIM; MANDELLI JÚNIOR, 2000, p.323).

Neste sentido a Constituição Federal de 1988 foi o marco divisor entre o atual regime democrático de direito e o regime militar ditatorial, o qual por mais de duas décadas foi imposto ao povo brasileiro.

Cadernos do Programa de Pós-Graduação em Direito PPGDir./UFRGS | Edição Digital | Porto Alegre | Volume XI | Número 2 | 2016 | P. 240 - 263 


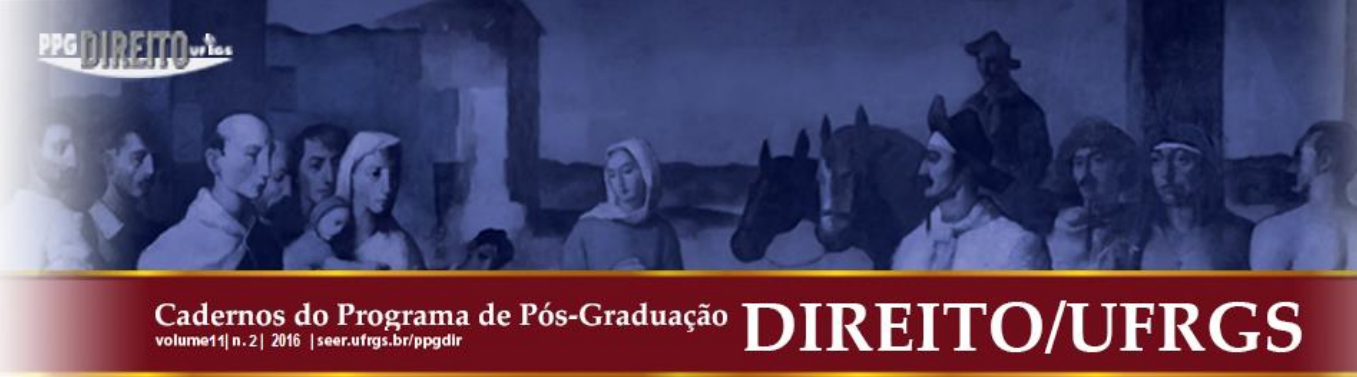

A Carta Magna passou a ser uma das Constituições mais avançadas do mundo, uma vez que elege a dignidade da pessoa humana como princípio e parâmetro primordial de todo o ordenamento jurídico (VALENTIM; MANDELLI JÚNIOR, 2000, p. 323-324).

Ainda discorrendo sobre o assunto, Valentim e Mandelli Júnior (2000, p. 324) explicam que a partir da sistematização regional dos Direitos Humanos na Europa, e também em decorrência da celebração da Convenção Européia de Direitos Humanos (1953), "foi adotado também na América esta tendência, tendo sido aprovada em 22 de novembro de 1969, a Convenção Americana de Direitos Humanos".

É certo que o Pacto de San José da Costa Rica tem como objetivo a consolidação, no Continente Americano da questão que envolve a prisão por dívidas alimentares. Visa também à efetividade de um regime de liberdades pessoais e justiça social, atrelado com a reafirmação nas instituições democráticas dos direitos humanos e fundamentais.

Em 1988, foi firmado o Protocolo Adicional à Convenção Americana sobre Direitos Humanos em Matérias de Direitos Econômicos Sociais e Culturais, também conhecido como Protocolo de San Salvador, e que trouxe em seu artigo $1^{\circ}$ a obrigação do Estado-parte em adotar medidas reais que permitam a efetiva do cumprimento dos direitos sociais, econômicos e culturais, observando regras de direito interno, bem como a realidade de cada País, haja vista que a Convenção não disciplina esses direitos, mas os recomenda aos Estados-parte, pois tais direitos estão contidos na Carta da Organização dos Estados Americanos (VALENTIM; MENDELLI JÚNIOR, 2000, p.326).

Apenas os Estados-membros da Organização dos Estados Americanos têm direito a aderir à Convenção Americana de Direitos Humanos, visando assegurar os direitos civis e políticos. Os Estados que participam dessa Convenção são: Argentina, Brasil, Chile, Colômbia, Costa Rica, El Salvador, Equador, Guatemala, Haiti, Honduras, Granada, Jamaica, México, Nicarágua, Peru, República Dominicana, Suriname, Uruguai e Venezuela (VALENTIM; MANDELLI JÚNIOR, 2000, p. 326).

A Convenção Americana de Direitos Humanos, também conhecida como Pacto de San José da Costa Rica, foi adotada no âmbito das Organizações dos Estados Americanos em San José da Costa Rica, na data de 22 de novembro de 1969, entrando em vigor internacional somente em 18 de julho de 1978, após o depósito do instrumento de ratificação ou de adesão de onze Estados (BRASIL, 1992). 


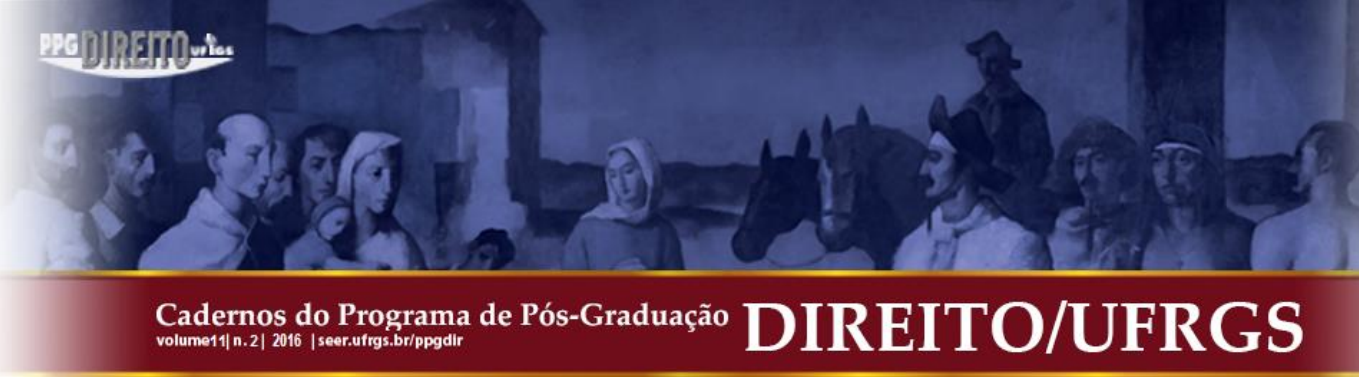

O Brasil somente ratificou sua adesão ao Pacto de San José da Costa Rica em 25 de setembro de 1992, por decreto-legislativo, depositando a respectiva Carta de Adesão no dia 6 de novembro do mesmo ano, pelo Decreto n. 678/1992, de 6 de novembro de 1992.

A demora em ratificar a Convenção Americana de Direitos Humanos no Brasil ocorreu em decorrência do regime ditatorial, que vigorava naquela ocasião.

A política externa brasileira na questão dos direitos humanos era muito resistente à adesão à via jurídica de proteção dos direitos fundamentais do homem, na medida em que ela importaria na revelação das práticas cruéis de repressão política, bem como na vulnerabilidade na imagem dos sucessivos governos militares perante as nações desenvolvidas, na Europa e na América do Norte.

Por outro lado, ressalta-se que dentre os principais direitos e liberdades estabelecidas na Convenção em questão, está previsto, em seu artigo $7^{\circ}$ o direito à liberdade pessoal, destacando-se o item 7, que diz "ninguém deve ser detido por dívidas. Esse princípio não limita os mandados de autoridades judiciários competentes expedidos em virtude de inadimplemento de obrigação alimentar" (BRASIL, 1992).

Apesar da Convenção somente permitir a prisão por dívidas, no caso de inadimplemento de obrigação alimentar, a Constituição Federal de 1988, em seu artigo $5^{\circ}$, inciso LXVII, estabelece que “[...] não haverá prisão civil por dívida, salvo a do responsável pelo inadimplemento voluntário e inescusável de obrigação alimentícia e a do depositário infiel” (BRASIL, 1988).

Neste sentido, observa-se um aparente conflito de normas, que no sistema jurídico brasileiro tem sido decidido pelo Supremo Tribunal Federal, no sentido de que o dispositivo constitucional não foi revogado, deixando apenas de ser aplicado, em decorrência do efeito paralisante estabelecido pelo Pacto de San José da Costa Rica, em relação à matéria infraconstitucional (SANTOS JÚNIOR, 2015).

O Pacto de San José da Costa Rica admite de forma excepcional a prisão civil por inadimplemento de a obrigação alimentar, e é omisso quanto à prisão civil do depositário infiel, permitida pela Constituição Federal de 1988.

A fim de sanar essa controvérsia, o Supremo Tribunal Federal editou a Súmula Vinculante $\mathrm{n}^{\mathrm{o}} 25$, a qual prevê que "[...] é ilícita a prisão civil do depositário infiel, qualquer que seja a modalidade do depósito" (BRASIL, 2015). 


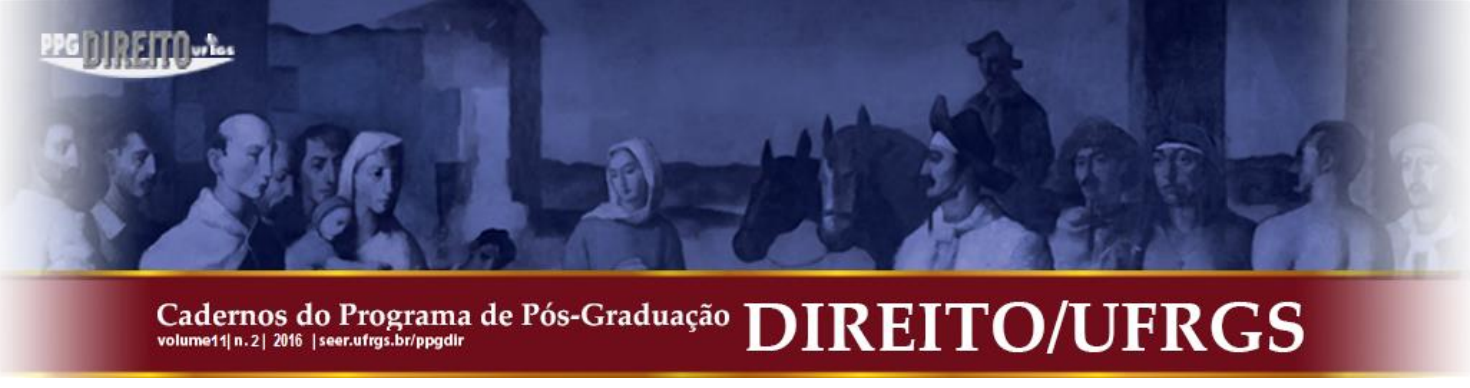

Ademais, o STJ sumulou seu entendimento, publicando a Súmula 419 do Superior Tribunal de Justiça, a qual estabelece que “(...) descabe a prisão civil do depositário judicial infiel".

Quanto ao devedor alimentar os artigos 19 da Lei $n^{\circ} 5.478 / 68$ e 733 do Código de Processo Civil prevêem como forma de assegurar o cumprimento do julgado ou do acordo, a decretação da prisão. Discorre Gonçalves (2005, p. 499):

Para garantir o fiel cumprimento da obrigação alimentar estabelece a lei diversas
providências, dentre elas a prisão do alimentante inadimplente (CF, art. $5^{\circ}$, LXVII;
CPC, art. 733 , caput e $\S \S 1^{\circ}, 2^{\circ}$ e $3^{\circ}$ ). Trata-se de uma das poucas exceções ao
princípio segundo o qual não há prisão por dívidas, justificada pelo fato de o
adimplemento da obrigação de alimentos atender não só ao interesse individual, mas
também ao interesse público, tendo em vista a preservação da vida do necessitado,
protegido pela Constituição Federal, que garante a sua inviolabilidade (art. $5^{\circ}$,
caput).

Na mesma esteira, Porto (2011, p. 115-116) salienta:

Ao tratarmos do pedido de prisão do devedor de alimentos, é necessário sabermos, desde logo, que este deve ser dirigido apenas contra o devedor relapso, recalcitrante, avesso ao cumprimento de suas obrigações. Certamente é esta a mens legis estabelecida nos arts. 733 do CPC e 19 da Lei de Alimentos. Com isto estamos a afirmar que o pedido de prisão do devedor visa atingir aquele que podendo implementar sua obrigação não o faz, revelando-se ladino. Esta posição leva por suporte o fato de que a prisão do devedor de alimentos não é pena, mas meio coercitivo de execução; visa compelir o devedor ao pagamento da dívida alimentar e não simplesmente puni-lo, tanto que pagando o devedor a prisão será levantada.

Nessa perspectiva, depreende-se que a prisão civil por dívida alimentar é uma exceção ao princípio segundo o qual não haverá prisão por dívidas, estando disciplinada na Constituição Federal, no Código de Processo Civil, na Lei de Alimentos e na Convenção Americana de Direito Humanos, como forma de assegurar o cumprimento da obrigação alimentar, preservando, assim, a vida do alimentando.

Após breve estudo histórico da prisão civil, insta conceituá-la.

Segundo Athanásio (2008, p. 48) a "Prisão Civil se realiza no âmbito do Direito Privado, consumando-se em face da dívida impagável, fundada em norma jurídica de natureza civil. (...)”. Para Cahali (2009, p. 752): "Decreta-se a prisão civil não como pena, não como fim de punir o executado pelo fato de não ter pagado a prestação alimentícia, mas sim com o fim, muito diverso, de coagi-lo a pagar". 


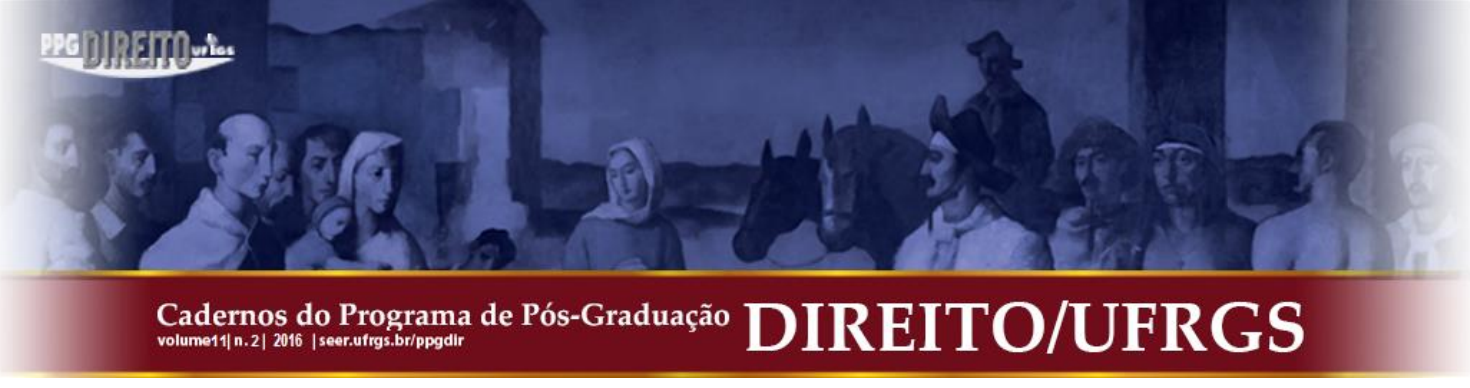

Para Porto (2011, p. 115-116) “a prisão do devedor de alimentos não é pena, ma meio coercitivo de execução que visa compelir o devedor ao pagamento da dívida alimentícia e não simplesmente puni-lo, tanto que pagando o devedor a prisão será levantada".

\begin{abstract}
(...) a execução tem, na quase totalidade dos casos, caráter patrimonial; nem todos os processos civis têm conteúdo exclusivamente econômico, mas a coação possível por parte do Estado visa, quase sempre, direta ou indiretamente, a resultado econômico. Assim, a prisão civil é meio executivo de finalidade econômica; prende-se o executado não para puni-lo, como se criminoso fosse, mas para forçá-lo indiretamente a pagar, supondo-se que tenha meios de cumprir a obrigação e queira evitar sua prisão, ou readquirir sua liberdade (CAHALI, 2009, p. 751).
\end{abstract}

A prisão civil não é pena, mas apenas um meio coercitivo o qual visa a compelir o devedor de alimentos a adimplir com sua obrigação, quando não a satisfaz voluntariamente.

\title{
2 CONDIÇÕES PARA SE DECRETAR A PRISÃO CIVIL
}

A lei não faz distinção com relação à origem do título que dá ensejo à cobrança da obrigação alimentar - se judicial ou extrajudicial - através de execução sob ameaça de coação pessoal. Não só a sentença, mas também a obrigação assumida extrajudicialmente, por meio de título extrajudicial, possibilitam a execução da obrigação alimentar através da prisão civil (DIAS, 2009, p. 513).

Antes mesmo de se decretar a prisão civil, nota-se que a medida coercitiva se apresenta em razão da necessidade de se efetivar os princípios da dignidade da pessoa humana, da solidariedade familiar e do "maior interesse da criança". Acerca deste ultimo, nota-se que "o ordenamento jurídico tem se atentado em assegurar o "maior interesse da criança”, dada tamanha a sua hipossuficiência perante os conflitos que se originam nas relações rompidas entre os seus genitores (LUCA; RINALDI JÚNIOR; 2014, p. 290)”.

Segundo Cahali (2009, p. 753), “(...) a prisão civil por dívida, como meio coercitivo para o adimplemento da obrigação alimentar, é cabível apenas no caso dos alimentos previstos nos arts. 1.566, III, e 1.694 do Código Civil de 2002, que constituem relação de direito de família."

Ademais, o STJ, ao editar a Súmula 309, estabeleceu que “(...) o débito alimentar que autoriza a prisão civil do alimentante é o que compreende as três prestações anteriores ao ajuizamento da execução e as que se vencerem no curso do processo". 


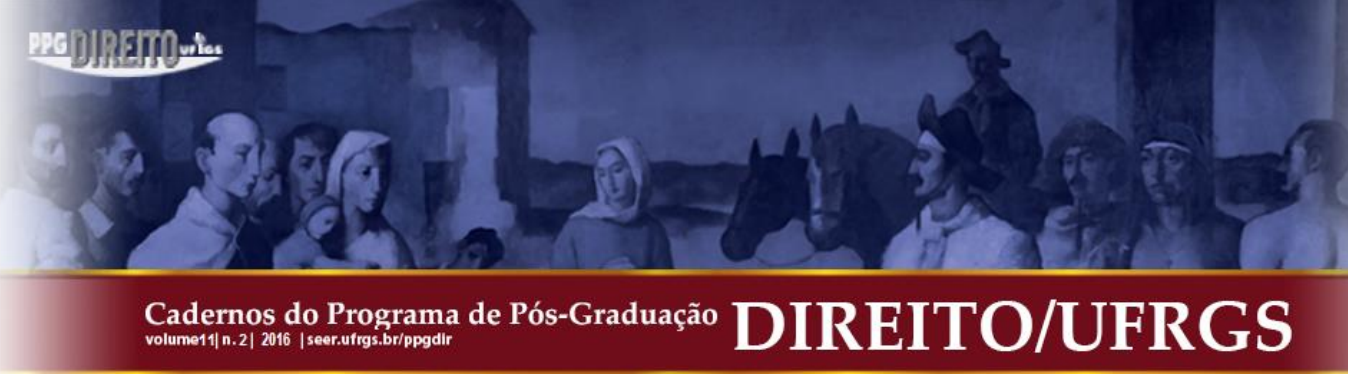

\begin{abstract}
Argumenta-se, para limitar a cobrança pelo rito do art. 733 do Código de Processo Civil às três últimas prestações vencidas, que a execução assim tão célere disciplinada no aludido dispositivo legal, acrescida da coerção através da cominação de sanção privativa de liberdade, só deve ser imposta para que não falte ao credor alimentos presumidamente indispensáveis à sua sobrevivência (GONÇALVES, 2005, p. 506-507).
\end{abstract}

Não é necessário que estejam vencidas três prestações para que o credor possa buscar a cobrança da obrigação alimentar. Isso ocorre em razão de que o inadimplemento de uma única parcela já autoriza a execução, podendo ainda ser cobradas parcelas alternadas.

As prestações que podem ser objeto de execução por meio da prisão civil do inadimplente são as três prestações anteriores ao ajuizamento da execução, bem como as que se vencerem no curso do processo, independentemente de tais obrigações constituírem títulos executivos judiciais ou extrajudiciais, não sendo necessário que o alimentando aguarde o vencimento de três prestações para que possa cobrar a obrigação.

Igualmente, o Código de Processo Civil, em seu artigo 733, determina que, “(...) na execução de sentença ou decisão, que fixa os alimentos provisionais, o juiz mandará citar o devedor, para em 3 (três) dias, efetuar o pagamento, provar que o fez ou justificar a impossibilidade de efetuá-lo" (BRASIL, 1973):

Na justificativa do não pagamento, infindáveis razões prestam-se para a defesa, como a superveniência de doença, o desemprego, a insolvência econômica, a perda de ente familiar, o nascimento de filho, a condenação criminal e prisão, a catástrofe nos meios de produção da qual advém a renda etc. (RIZZARDO, 2007, p.842).

Na mesma esteira, apregoa Gonçalves (2005, p. 503): “(...) da composição dos textos do Código de Processo Civil e da Lei de Alimentos resulta o entendimento de que a prisão civil do devedor pode ser requerida tanto no caso de não-pagamento dos alimentos definitivos, como também dos provisórios e provisionais".

Em relação à citação do executado, Dias (2009, p. 514) explicita:

Proposta a execução pelo rito da coação pessoal (CPC 733), o réu é citado para pagar, provar que pagou ou justificar a impossibilidade de fazê-lo, no prazo de três dias. Como se trata de ação de estado, o réu deverá ser citado pessoalmente e não pelo correio (CPC 222 a), mas nada impede que a citação ocorra por hora certa (CPC 227), até porque costuma o executado esquivar-se do oficial de justiça. Também nada obsta que a citação seja levada a efeito por edital (CPC 231). Nessa hipótese, porém, não basta a singela assertiva do credor de que o devedor se encontra em lugar incerto ou não sabido. Como em todas as outras ações de estado, é indispensável que o juiz, de ofício, adote providências para a localização do devedor, antes de determinar a citação ficta. 


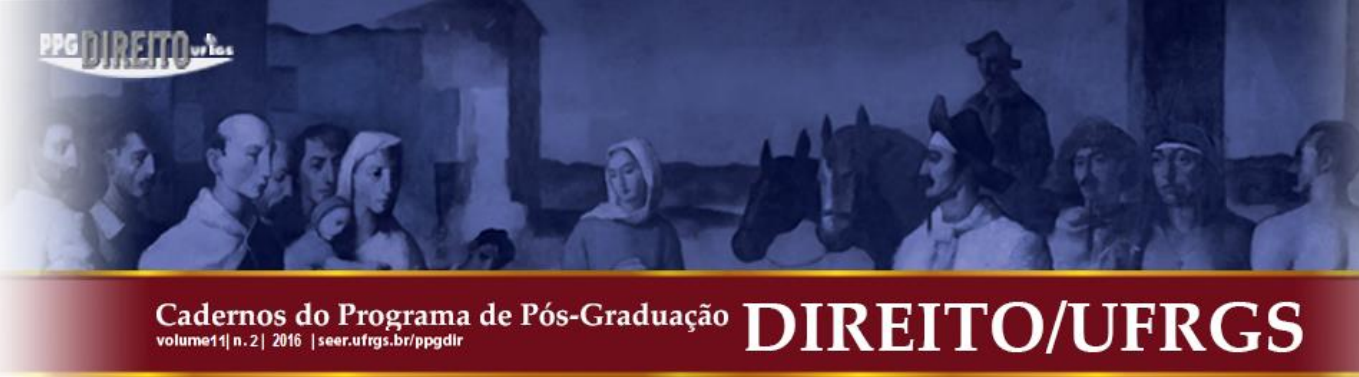

Logo, ao ser citado, o executado tem três alternativas para evitar sua prisão, quais sejam: pagar o débito existente; provar que está cumprindo mensalmente com sua obrigação alimentar; ou justificar que está impossibilitado de efetuar o pagamento, desde que seja por algo justo, como, por exemplo, no caso de desemprego.

Aceita a justificativa, ou seja, reconhecido que o devedor não tem condições de proceder ao pagamento, isso não enseja a extinção do processo executório, pois, ainda que o devedor se livre da prisão, a dívida não desaparece e a execução pode prosseguir pelo rito da expropriação (DIAS, 2009, p. 516).

No caso de o executado se prontificar a pagar uma parcela da dívida, o alimentando não pode manter uma postura intolerável, de modo a não aceitar a proposta.

Por outro lado, aponta-se como necessário a verificação de possibilidade de o restante da dívida ser exequível através de prestações periódicas, bem como se as razões aduzidas para o parcelamento da obrigação são realmente ponderáveis.

Realizado o acordo e não cumprido, não se deve afastar o prosseguimento da execução pelo mesmo rito, tendo em vista que a dívida não perde a atualidade. Quando são rejeitadas as alegações do devedor, cabe ao juízo decretar a prisão do obrigado, depois de ouvir o Ministério Público.

O parágrafo $1^{\circ}$ do artigo 733 do Código de Processo Civil determina que "se o devedor não pagar, nem se escusar, o juiz decretar-lhe-á a prisão pelo prazo de 1 (um) a 3 (três) meses" (BRASIL, 1973). Por sua vez, a Lei n ${ }^{\circ}$ 5.478/68 estabelece que “o juiz, para instrução da causa ou na execução da sentença ou do acordo, poderá tomar todas as providências necessárias para o seu esclarecimento ou para o cumprimento do julgado ou do acordo, inclusive a decretação da prisão do devedor até 60 (sessenta) dias” (BRASIL, 1968).

O período de duração da coação pessoal é questão que apresenta grande controvérsia, em nosso ordenamento jurídico, razão pela qual surgiram na doutrina e na jurisprudência opiniões divergentes.

Da decisão que decretar a prisão do devedor, caberá agravo de instrumento, contudo, a interposição do recurso não suspende a execução da ordem de prisão, conforme disposto pelo artigo 19 , parágrafos $2^{\circ}$ e $3^{\circ}$, da Lei $n^{\circ} 5.478 / 68$.

A prisão do inadimplente da obrigação alimentar não poderá ultrapassar o prazo de máximo de sessenta dias estabelecido pela Lei $n^{\circ} 5.478 / 68$, porém, ante a não fixação de 


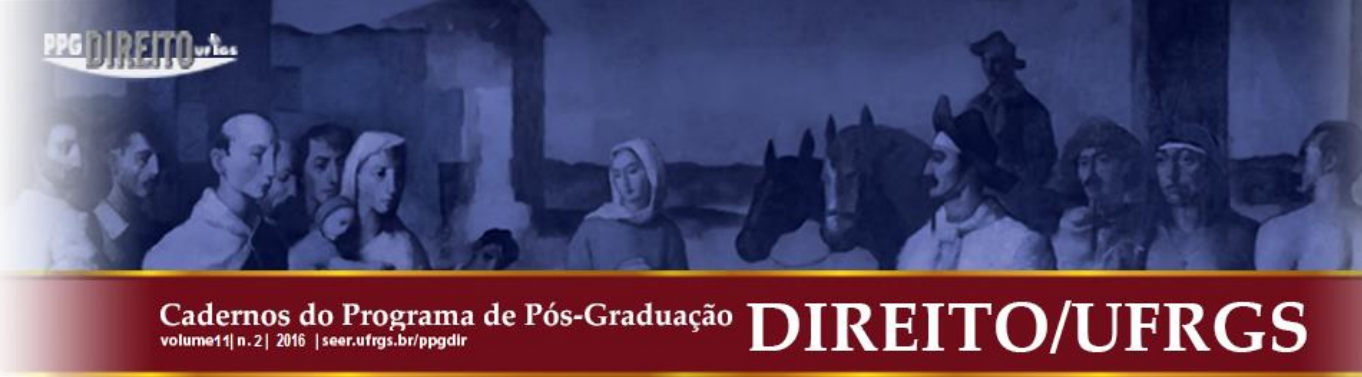

prazo mínimo para a decretação da prisão civil, será adotado o prazo previsto no Código de Processo Civil, que será de no mínimo trinta dias.

A prisão do devedor de alimentos é tão somente meio coercitivo, o qual visa a compelir o devedor ao pagamento da dívida alimentícia e não é pena, haja vista que não tem por objetivo punir o devedor (PORTO, 2011, p. 115-116).

O Código de Processo Civil fixa, em seu artigo 733, parágrafo $2^{\circ}$, que "o cumprimento da pena não exime o devedor do pagamento das prestações vencidas e vincendas" (BRASIL, 1973).

De igual forma, dispõe o artigo 19, parágrafo $1^{\text {o }}$, da Lei $\mathrm{n}^{\mathrm{o}}$ 5.478/68: “[...] o cumprimento integral da pena de prisão não eximirá o devedor do pagamento das prestações alimentícias, vincendas ou vencidas e não pagas" (BRASIL, 1968).Dias (2009, p. 525) comenta, a propósito:

Ainda que o devedor não possa ser preso novamente pelo inadimplemento da mesma dívida, o cumprimento da pena não o dispensa do pagamento. Assim, no mesmo processo executório, pode prosseguir a cobrança do débito ou mediante cumprimento da sentença (CPC 475-I) ou pelo rito da expropriação (CPC 646).

Do exposto, depreende-se que, uma vez pagas as prestações em atraso, o juiz suspenderá imediatamente o cumprimento da ordem de prisão, podendo a prisão ser reiterada, desde que o pedido não envolva o período anterior; entretanto, caso haja o cumprimento integral da pena, a obrigação alimentar não será extinta, podendo prosseguir a cobrança mediante o cumprimento da sentença ou através do rito da expropriação.

\section{INGRESSO DOS TRATADOS NO ORDENAMENTO JURÍDICO BRASILEIRO}

A Constituição Federal de 1988 atribui, em seu artigo 84, VIII, competência privativa ao Presidente da República para celebrar tratados, convenções ou ainda atos internacionais, ficando eles sujeitos ao referendo do Congresso Nacional.Por sua vez, o artigo 49, I da Constituição Federal confere ao Congresso Nacional competência exclusiva para resolver definitivamente sobre tratados, acordos ou atos internacionais os quais tenham como objetivo acarretar encargos ou compromissos gravosos ao patrimônio nacional (BRASIL, 1988).

Entende-se que para um tratado internacional ter força obrigatória em relação ao povo brasileiro, é necessário o cumprimento de três fases distintas: celebração do tratado pelo Presidente da República, em nome da República Federativa do Brasil 


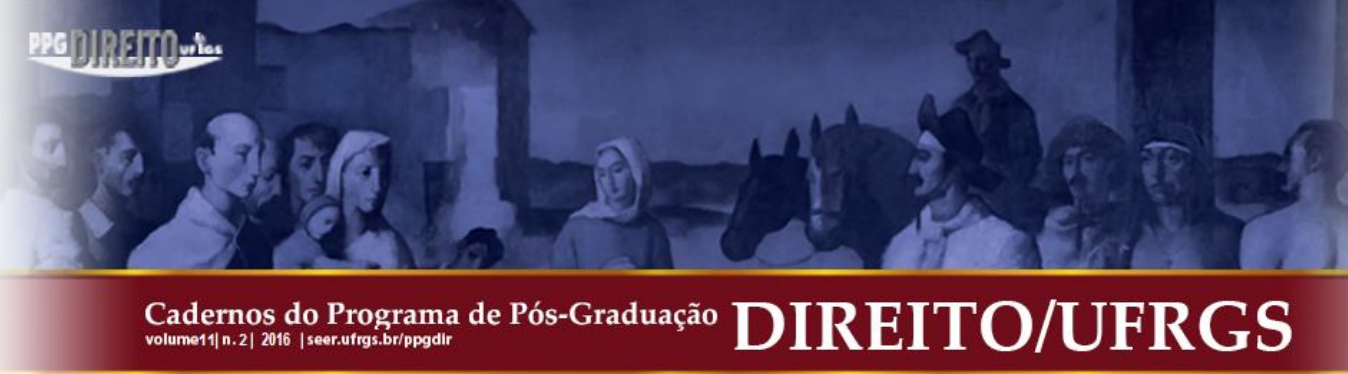

(CF/88, art. 84, VIII, ver, ainda, os artigos conexos da mesma CF, $5^{\circ}, \S 2^{\circ}, 102$, IIIb); aprovação definitiva pelo Congresso Nacional, por Decreto Legislativo (CF, 49, I) e promulgação pelo Presidente da República, via decreto (CF, art. 82, IV). Cumpridas essas três fases, ou seja, celebração; aprovação definitiva e promulgação, estará o tratado internacional incorporado ao ordenamento interno brasileiro, como norma pronta e apta para produzir os seus efeitos em relação ao Brasil (GARBUGLIO, 2010).

Nota-se que após a promulgação, se deve analisar que posição hierárquica a norma internacional ocupa no ordenamento jurídico brasileiro.

No que tange o conflito entre as normas de direito interno dos Estados e as normas dos Tratados Internacionais, existem duas teorias nas quais se debate a necessidade de um procedimento de internalização da norma internacional na ordem jurídica do Estado signatário, bem como a posição hierárquica adotada por essa norma, dentro do ordenamento jurídico brasileiro.

Segundo a teoria dualista, adotada por Heinrich Triepel, o Direito Internacional e o Direito Interno de cada Estado signatário possuem objetivos próprios, fundamentados em fontes jurídicas próprias, o que acarreta um sistema distinto para cada ordenamento jurídico (MARINHO, 2008, p. 12).

Assim, para que um tratado passe a produzir efeitos na ordem do Estado signatário, é necessário à criação de uma lei específica que determine sua incorporação, fazendo com que a norma internacional adquira status de norma estatal e, caso houvesse divergência entre as normas, a mais recente derrogaria a mais antiga (lex posteriori derogatlegi priori).

Por outro lado, os adeptos da teoria monista, como Hans Kelsen, sustentam que o Direito Internacional e o Direito Interno formam um sistema único, desdobrado entre ordenamento jurídico interno e internacional (MARINHO, 2008, p. 12-13).

Assim, para os defensores da teoria monista, havendo conflito entre normas, tal conflito poderia ser solucionado de três formas: com a prevalência do Direito Interno sobre o Direito Internacional; com a primazia da norma internacional sobre a norma interna; ou, ainda, considerando que a norma internacional e a norma interna integram o mesmo patamar hierárquico, a mais recente deveria prevalecer sobre a mais antiga, o que se denomina monismo moderado.Na mesma linha, frisa Ariosi (2015):

O monismo surge como contraponto do dualismo defendido por Triepel. Grosso modo, a teoria monista não aceita a existência de duas ordens jurídicas autônomas, independentes e não-derivadas. $\mathrm{O}$ monismo sustenta a tese da existência de uma única ordem jurídica. Esta concepção apresenta duas variáveis de compreensão: a 


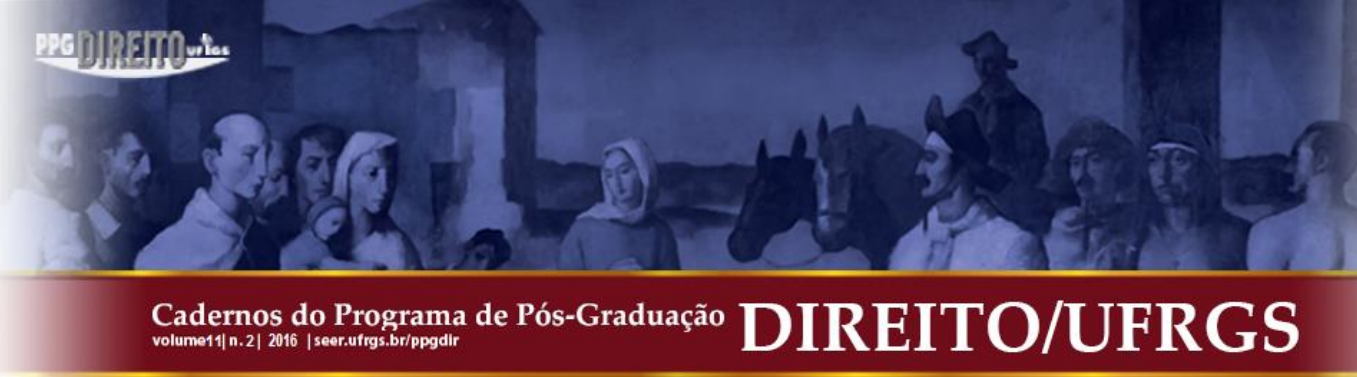

que defende a primazia do Direito interno e, a outra, a primazia do Direito Internacional.

É certo que a Constituição Federal deixou uma lacuna normativa, causando divergência entre os doutrinadores com relação à teoria adotada.

Parte da doutrina e da jurisprudência sustenta que o Supremo Tribunal Federal teria se filiado a um monismo moderado, em razão do julgamento do RE n. ${ }^{\circ}$ 80.004/SE, em 01 de junho de 1977.Entretanto, no julgamento do Agravo Regimental na Carta Rogatória 8279, de 17 de junho de 1998, pelo Supremo Tribunal Federal, o Ministro Relator Celso de Mello enfatiza que, já que a Constituição Federal não consagrou o tema de convenções internacionais ou tratados de integração, é necessária a conclusão do ciclo de transposição da norma internacional para o direito interno, a fim de que ela possa ser invocada, de sorte que, enquanto não ocorrer a transposição, as normas internacionais não podem ser aplicadas imediatamente no âmbito doméstico do Estado brasileiro (BRASIL, 1998).

Assim, percebe-se que o Brasil adota a teoria dualista, tendo em vista que, segundo o julgamento do Agravo Regimental na Carta Rogatória 8279, para que uma norma internacional passe a produzir efeitos na ordem do Estado brasileiro, é necessária a criação de uma lei específica determinando sua incorporação, argumento sustentado pela teoria dualista.

\section{CONTROVÉRSIAS DO STATUS JURÍDICO DA PRISÃO CIVIL}

Aos tratados internacionais, isto é, àqueles que não versam sobre direitos humanos, é conferida a natureza de norma infraconstitucional (lei ordinária federal), por força do artigo 102, III, b, e do artigo 105, III, a, ambos da Carta Magna, conforme leciona Souza (2010, p. 48).

A Emenda Constitucional $n^{\circ} 45$, promulgada em 30 de dezembro de 2004, entre outras alterações, introduziu no artigo $5^{\circ}$ da Constituição Federal o parágrafo $3^{\circ}$, o qual estabelece que "[o]s tratados e convenções internacionais de direitos humanos que forem aprovados, em cada Casa do Congresso Nacional, em dois turnos, por três quintos dos votos os respectivos membros, serão equivalentes às emendas à Constituição" (BRASIL, 2004).Nesse sentido, Souza (2010, p. 48) conclui: 


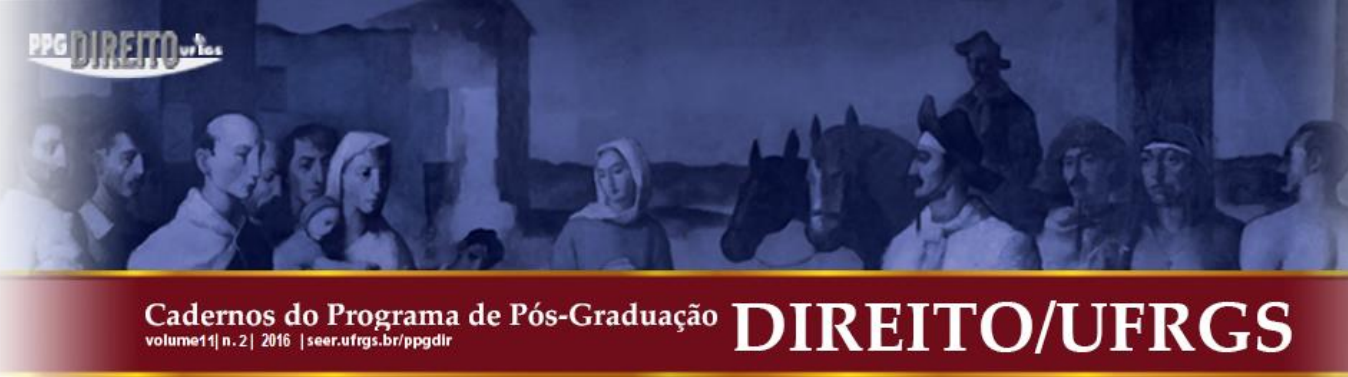

do parágrafo $3^{\circ}$ do artigo $5^{\circ}$ da Constituição, que terão força de emenda constitucional. A controvérsia gira em torno dos tratados internacionais de direitos humanos que foram ratificados antes da emenda e que, embora tenham contado com o quorum de três quintos dos membros de cada casa, não foram aprovados em dois turnos de votação.

Em razão disso, surgem quatro correntes acerca da posição hierárquica ocupada pelos tratados internacionais, no ordenamento jurídico brasileiro: a primeira corrente sustenta a igualdade entre o tratado e a lei federal; a segunda sustenta a supra constitucionalidade, alegando que os tratados estão acima até da Constituição Federal; a terceira corrente sustenta a hierarquia constitucional de todos os tratados protetores de direitos humanos; e, por fim, a quarta corrente sustenta a hierarquia infraconstitucional, mas supra legal, dos tratados ratificados antes da Emenda Constitucional no 45/2004 (SOUZA, 2010, p. 48).

A primeira corrente, a qual defende a igualdade entre o Tratado e a Lei Federal, foi acolhida pelo Supremo Tribunal Federal por muitos anos; de acordo com esse entendimento, os tratados são normas infraconstitucionais os quais têm a mesma força normativa que as leis ordinárias, revogando as normas anteriores que com ela sejam incompatíveis. Assim, todas as disposições gerais anteriores, contrárias a essa norma serão revogadas, exceto as leis especiais, conforme explica Souza (2010, p. 49).

Na mesma esteira, Marinho (2008, p. 18) ensina que:

sobre a posição hierárquica ocupada pelos tratados internacionais no ordenamento jurídico brasileiro vinha sendo a seguida pelo Supremo Tribunal Federal. Os adeptos desta vertente afirmam que qualquer norma decorrente de tratado internacional possui status de lei ordinária, tendo caráter infraconstitucional. Utilizam como base o artigo 102, III, b da Constituição Federal e sua interpretação literal. Afirmam que, se a própria Constituição atribui competência ao STF para julgar, mediante recurso extraordinário, as causas decididas em única ou última instância, quando a decisão recorrida declarar a inconstitucionalidade de tratado ou lei federal, reconhece ela posição hierárquica inferior de todos os tratados internacionais, de direitos humanos ou não, face o texto constitucional.

Entretanto, Souza (2010, p. 49-50) adverte que tal corrente é criticada pela doutrina, em razão de ela ser contrária ao princípio da boa-fé no cumprimento dos tratados internacionais, além de afrontar a Convenção de Viena, a qual dispõe, em seu artigo 27, que os Estados não poderão invocar disposições de direito interno para não cumprirem o disposto nos tratados dos quais sejam parte.

Por seu turno, Alves Ribeiro e Aguiar Filho (2009, p. 07) complementam: 


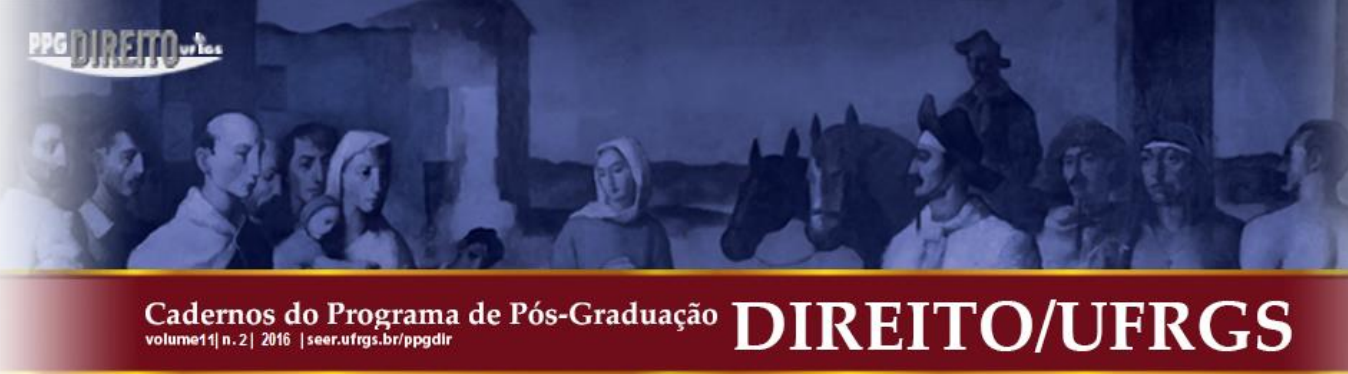

aprovados por maioria simples deveriam permanecer sendo absorvidos pelo
ordenamento do país como lei infraconstitucional, o conflito entre referidas normas
federais de mesmo nível, leis ordinárias e tratados internacionais não elevados por
emendas constitucionais, deveriam ser resolvidos pela relação entre lei especial e
geral.

A despeito de o Supremo Tribunal Federal ter adotado por muitos anos a primeira corrente, a qual sustenta que as normas infraconstitucionais têm a mesma força normativa que as leis ordinárias, atualmente essa corrente tem sido criticada pela doutrina, em razão da afronta provocada por ela à Convenção de Viena e por ser contrária ao princípio da boa-fé, no cumprimento dos tratados internacionais.

A segunda corrente, por sua vez, sustenta a supra constitucionalidade dos tratados, de acordo com Souza (2010, p. 50), “[o]s defensores dessa corrente acreditam que os tratados internacionais sobre direitos humanos têm caráter supra constitucional, ou seja, prevalecem sobre as normas da Constituição Federal”.

Ainda discorrendo sobre o assunto, Emerique e Guerra (2008, p. 03) acrescentam: “(...) significa que nem mesmo a emenda constitucional suprimiria a normativa internacional subscrita pelo Estado quando a matéria correspondesse aos direitos humanos".

Contudo, na opinião de Souza (2010, p. 51), esse entendimento é criticado pelos doutrinadores, por ser considerado abusivo em relação ao que estabelece a Constituição Federal, em seu artigo $5^{\circ}$, parágrafo $2^{\circ}$.

Nota-se que os tratados internacionais têm hierarquia superior às normas da própria Constituição, tal corrente não foi incorporada pelo ordenamento jurídico brasileiro.

Diferentemente disso, a terceira corrente sustenta que os tratados internacionais de direitos humanos recebem, no ordenamento jurídico brasileiro, status de norma constitucional.

Nesse sentido, Marinho (2008, p. 15) explicita: "Segundo parte da doutrina e da jurisprudência, os tratados internacionais que versem sobre direitos humanos adquirem status de norma constitucional".

Na mesma esteira, Souza (2010, p. 51) enfatiza:

Defendida por Flávia Piovesan, Francisco Rezek, Odete Novais Carneiro Queiroz, Vidal Serrano Nunes Júnior, pelo ministro do STF Celso de Mello, entre outros juristas, essa corrente estabelece que os tratados de proteção dos direitos humanos têm natureza constitucional, que decorre do artigo $5^{\circ}, \S 2^{\circ}$, da Constituição Federal. 


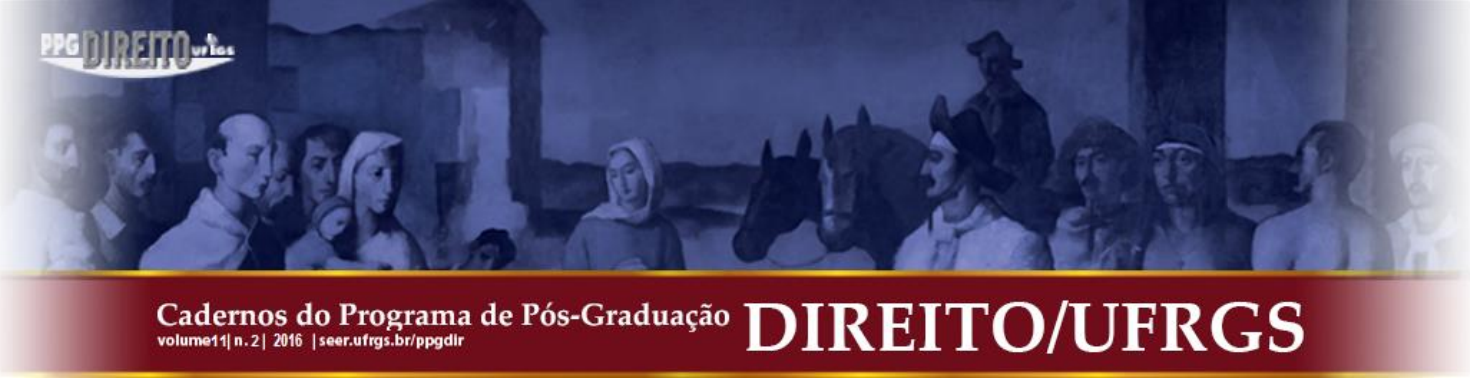

É inegável que o artigo $5^{\circ}$, parágrafo $2^{\circ}$, da Constituição Federal de 1988 estabelece que “[o]s direitos e garantias expressões nesta Constituição não excluem outros decorrentes do regime e dos princípios por ela adotados, ou dos tratados internacionais em que a República Federativa do Brasil seja parte" (BRASIL, 1988).

Em virtude dessas considerações, depreende-se que, segundo o entendimento adotado por essa corrente, os direitos previstos nos tratados internacionais de direitos humanos dos quais o Brasil é parte integram o rol de direitos estabelecidos na Constituição Federal, adquirindo, portanto, status de norma constitucional.

Por fim, a quarta corrente sustenta a hierarquia infraconstitucional, mas supra legal, dos tratados internacionais de direitos humanos ratificados antes da promulgação da Emenda Constitucional no 45/2004.

Nos últimos anos, o embate existente no Supremo Tribunal Federal dizia respeito à hierarquia constitucional dos tratados, corrente sustentada pelo ministro Celso de Mello, e a corrente defendida pelo ministro Gilmar Mendes, para quem havia uma hierarquia infraconstitucional, embora supra legal dos tratados, ou seja, segundo esse entendimento, os tratados de direitos humanos estão acima da lei, mas abaixo da Constituição (SOUZA, 2010, p.53).

Não obstante, com a entrada em vigor da Emenda Constitucional n. ${ }^{\circ}$ 45/2004, o cenário se alterou, pois essa Emenda trouxe significativas mudanças, no que concerne ao Direito Internacional, uma vez que incluiu o $\S 3^{\circ}$ no artigo $5^{\circ}$ da Constituição Federal, alterando a abordagem que vinha sendo dada aos tratados internacionais, em especial àqueles que tratam de direitos humanos, conforme leciona Marinho (2008, p. 21).

Concluem Linard e Alcantara (2010, p. 3682):

Portanto, dentro desse contexto denominado de Estado de Direito Internacionalista foi promulgada a Emenda Constitucional $n^{\circ} 45$ de 30 de dezembro de 2004, acrescentando o $\$ 3^{\circ}$ ao Art. $5^{\circ}$ da CF trazendo em seu texto que: "Os tratados e convenções internacionais sobre direitos humanos que forem aprovados, em cada Casa do Congresso Nacional, em dois turnos, por três quintos dos votos dos respectivos membros, serão equivalentes às emendas constitucionais.", respeitando, dessa forma o disposto no art. 49, I, da Constituição Federal.

Nesse contexto, mais uma vez, Marinho (2008, p. 22) explica que a alteração não colocou fim aos debates, visto que surgiram discussões a propósito do status normativo adotado pelos tratados internacionais ratificados antes da edição da Emenda Constitucional n. ${ }^{\circ}$ $45 / 2004$.

Cadernos do Programa de Pós-Graduação em Direito PPGDir./UFRgS | Edição Digital | Porto Alegre | Volume XI | Número 2 | 2016 | P.240 - 263 


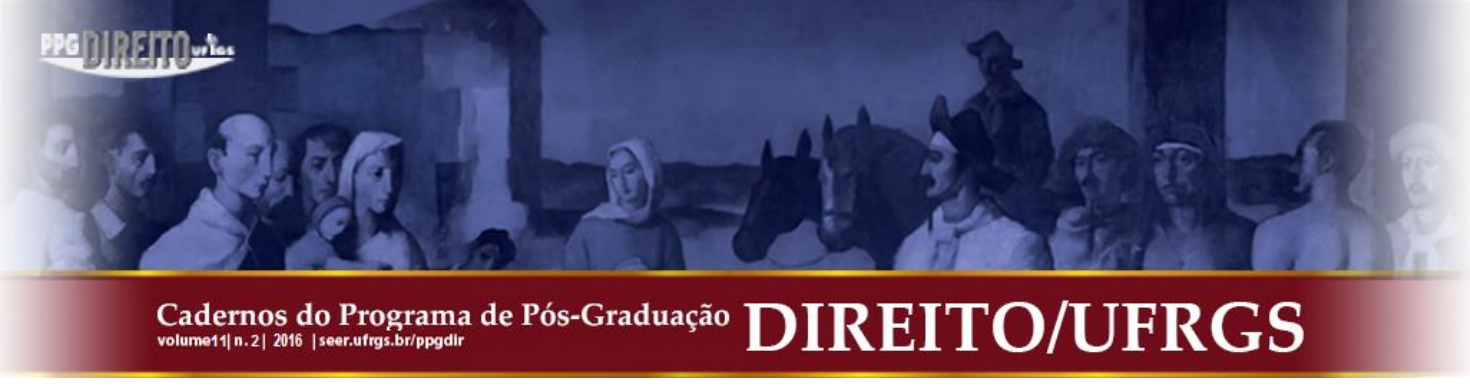

Por força da Emenda Constitucional n..$^{\circ}$ 45/2004, estabeleceu-se uma regra relativa à admissão dos tratados internacionais com status de Emenda Constitucional. Entretanto, quando da promulgação da referida Emenda, o Pacto de San José da Costa Rica já havia sido ratificado, fazendo com que a exigência contida no parágrafo $3^{\circ}$ do artigo $5^{\circ}$ da Constituição Federal trouxesse à tona uma nova discussão quanto aos pactos anteriores à promulgação da Emenda Constitucional (LINARD; ALCANTARA, 2010, p. 3682).

Conforme entendimento de Marinho (2008, p. 23),

(...) ao se considerar que os tratados internacionais de direitos humanos ratificados antes da Emenda Constitucional 45/2004 já possuíam status de norma constitucional, versando eles sobre garantias e direitos fundamentais, conforme defendido pela primeira corrente, qualquer emenda tendente a aboli-los será inconstitucional, nos termos do artigo $60, \S 4^{\circ}$, IV da Constituição Federal. Desta forma, só se pode concluir que a Emenda Constitucional 45/2004 se aplica apenas a tratados de direitos humanos que ainda não foram ratificados, mantendo os anteriores a ela o status de norma constitucional, mesmo que não tenham sido aprovados por quorum especial e nem tenham sido votados em dois turnos em ambas as Casas do Congresso Nacional.

Assim, em 03 de dezembro de 2008, a Suprema Corte, ao julgar os Recursos Extraordinários n. 466.343-SP e 349.703-RS e, em conjunto, os Habeas Corpus n. 87.585-TO e 92.566-SP, definiu que é ilícita a prisão civil do depositário infiel, permanecendo apenas no ordenamento jurídico brasileiro a prisão civil do devedor de alimentos, acolhendo, desse modo, a tese da supra legalidade dos tratados internacionais de direitos humanos que não foram aprovados de acordo com a alteração trazida pela Emenda Constitucional no 45/2004 (SOUZA, 2010, p. 53).

Em outras palavras, Cahali (2009, p. 752-753) frisa: “A prisão por dívida foi banida de nossa legislação; a dívida alimentar, entretanto, constitui exceção à regra [...]”.

Por conseguinte, os tratados internacionais de direitos humanos não ratificados pelo Brasil, na forma estabelecida no artigo $5^{\circ}$, parágrafo $3^{\circ}$ da Constituição Federal, têm natureza supra legal, quer dizer, estão hierarquicamente abaixo da Constituição Federal, mas acima da Legislação, fazendo com que as Leis que previam e regulamentavam a prisão civil do depositário infiel fossem revogadas, preexistindo somente a prisão civil do devedor de alimentos (SOUZA, 2010, p. 57).

Por tais razões, conclui-se que, antes da promulgação da Emenda Constitucional $n^{\circ}$ 45/2004, existia grande controvérsia a respeito da posição hierárquica adotada pelos tratados internacionais, no ordenamento jurídico brasileiro, mas, após a promulgação da referida 


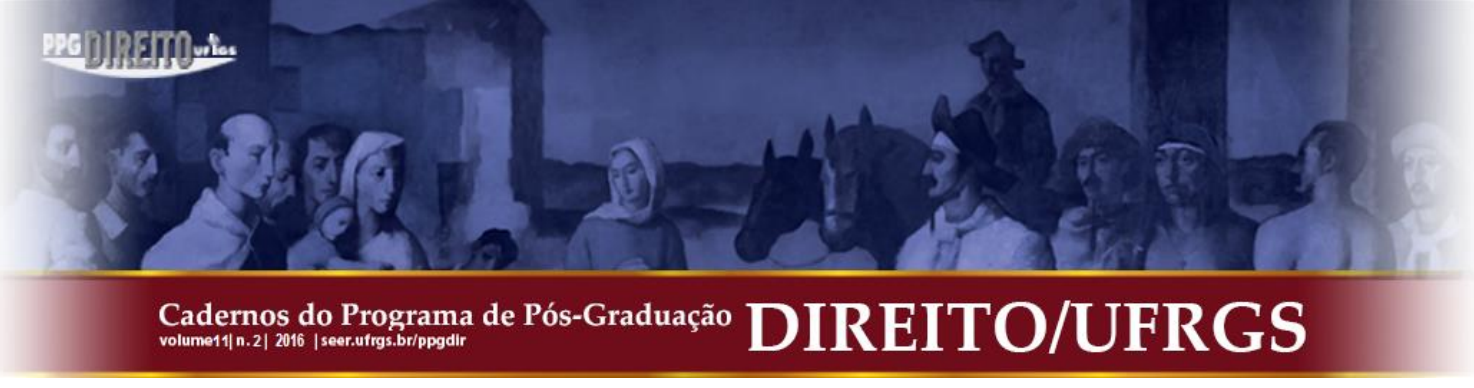

Emenda, tais tratados adquiriram status de norma supra legal. Por isso, os tratados internacionais que não forem aprovados com o quorum de três quintos em dois turnos nas duas Casas do Congresso Nacional terão caráter de norma supra legal, estando, portanto, acima das leis, mas abaixo da Constituição Federal.

\section{DA ANÁLISE JURISPRUDENCIAL}

Após a promulgação da Emenda Constitucional n. ${ }^{\circ}$ 45/2004, os tratados internacionais que fossem aprovados com o quórum previsto no artigo $5^{\circ}$, parágrafo $3^{\circ}$ da Constituição Federal, teriam caráter de Emenda Constitucional.

No entanto, depois dessa alteração surgiram discussões acerca do status normativo adotado pelos tratados internacionais ratificados antes da edição da Emenda Constitucional n. ${ }^{\circ}$ $45 / 2004$.

Com efeito, para a Décima Sétima Câmara Cível do Tribunal de Justiça de Minas Gerais, os tratados internacionais foram elevados ao status de norma supra legal em razão de o Pacto de San José da Costa Rica ter sido ratificado pelo Brasil sem qualquer reserva:

HABEAS CORPUS - PRISÃO CIVIL - DEPOSITÁRIO INFIEL PRISÃO CIVIL - IMPOSSIBILIDADE - PACTO DE SAN JOSÉ DA COSTA RICA - STATUS DE NORMA SUPRALEGAL - REVOGAÇÃO DOS DISPOSITIVOS INFRACONSTITUCIONAIS QUE COM ELE CONFLITEM ENTENDIMENTO CONTEMPLADO PELOS TRIBUNAIS SUPERIORES ORDEM CONCEDIDA. O Pacto de San José da Costa Rica, consolidado em 1969, que prevê a possibilidade de prisão civil apenas do devedor de alimentos, foi ratificado em nosso ordenamento jurídico, através do Decreto de $\mathrm{n}^{\circ} 678$, em 06.11.1992, ou seja, sob a égide da Carta Constitucional de 1988. Inicialmente, a jurisprudência das Cortes Superiores, sobretudo do Supremo Tribunal Federal, direcionou-se no sentido da não-revogação do art. $5^{\circ}$, LXVII, da CR/88, que dispõe, de forma expressa, acerca do cabimento da prisão civil do depositário infiel. Sob o influxo da necessidade de, cada vez mais, se garantir eficácia aos direitos fundamentais, o Supremo Tribunal Federal, em diversos julgamentos, aplicando uma interpretação sistemática dos dispositivos constitucionais, visando concretizar os fundamentos da República Federativa do Brasil, elencados no art. $3^{\circ}$ da Carta Magna, tem atribuído ao Pacto de San José da Costa Rica "“" status " " normativo supra legal, colocando-o acima da legislação infraconstitucional interna, contudo, abaixo das normas constitucionais, eis que não observados os requisitos do $\S 3^{\circ}$, do art. $5^{\circ}$, da Magna Carta. A elevação de tratados e convenções internacionais ao "“، status "" de norma supra legal se deve ao fato de que o referido tratado de San José da Costa Rica, ratificado pelo Brasil sem qualquer reserva, estabelece uma ampliação de direitos fundamentais consagrados pela nossa Constituição. Note-se que, ao atribuir caráter supra legal à Convenção Americana sobre Direitos Humanos - Pacto de San José da Costa Rica, que, repita-se, limita a hipótese de prisão civil apenas ao devedor de alimentos, houve a revogação de toda legislação interna infraconstitucional, que com ele conflite. Assim, em razão do 


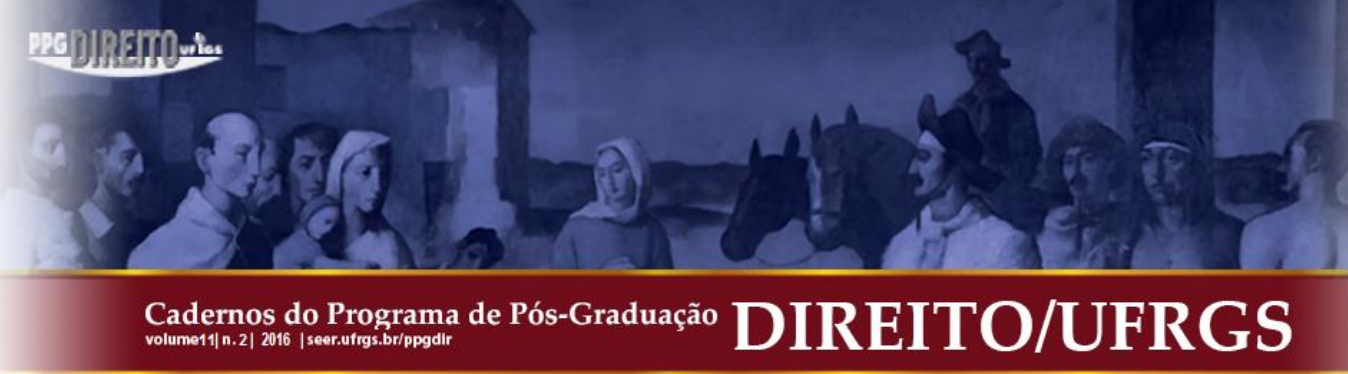

referido posicionamento, acerca da hierarquia supra legal dos tratados e convenções internacionais que versem sobre direitos humanos, tem-se entendido não ser cabível a prisão civil do depositário infiel, mesmo nas hipóteses de depósito judicial, em razão da revogação dos dispositivos infraconstitucionais que tratam da matéria. (MINAS GERAIS, 2009).

Dessa forma, verifica-se que o Tribunal de Justiça de Minas Gerais reconheceu a elevação do Pacto de San José da Costa Rica a norma supra legal, colocando-o acima da legislação infraconstitucional interna, mas abaixo das normas constitucionais.

Igualmente, a Primeira Câmara de Direito Comercial do Tribunal de Justiça de Santa Catarina, ao julgar Habeas Corpus Preventivo, estabeleceu que as convenções internacionais sobre direitos humanos que ainda não foram submetidas ao procedimento previsto no artigo $5^{\circ}$, parágrafo $3^{\circ}$ da Constituição Federal, terão caráter de norma supra legal, permitindo a prisão civil somente no caso de dívida por alimentos:

HABEAS CORPUS PREVENTIVO. PRISÃO CIVIL. VIABILIDADE DE DECRETAÇÃO TÃO SOMENTE CONTRA DEVEDOR DE ALIMENTOS. HIPÓTESE DIVERSA. ART. 11 DO PACTO INTERNACIONAL SOBRE DIREITOS CIVIS E POLÍTICOS, DE 1966, E ART. 7º, 7, DA CONVENÇÃO AMERICANA SOBRE DIREITOS HUMANOS (PACTO DE SAN JOSÉ DA COSTA RICA, DE 1969). STATUS SUPRALEGAL DAS DISPOSIÇÕES ALUDIDAS SALVO-CONDUTO. DEFERIMENTO. (SANTA CATARINA, 2007).

Com efeito, ao adquirir status supra legal, o ordenamento jurídico brasileiro tornou incompatível qualquer disposição normativa referente à prisão civil, exceto no caso de dívida por alimentos.

Ademais, a décima Oitava Câmara Cível do Tribunal de Justiça do Rio Grande do Sul seguiu o entendimento do Supremo Tribunal Federal:

HABEAS CORPUS. PROMESSA DE COMPRA E VENDA. EXCECUÇÃO. PRISÃO CIVIL. DEPOSITÁRIO INFIEL. O Pacto de San José da Costa Rica, tratado internacional de direitos humanos, possui, segundo entendimento do Supremo Tribunal Federal, caráter de norma supra legal, inviabilizando, assim, qualquer hipótese de prisão civil prevista na legislação infraconstitucional, com exceção do devedor inescusável de prestação alimentar. ORDEM CONCEDIDA POR DECISÃO MONOCRÁTICA DO RELATOR. (RIO GRANDE DO SUL, 2011).

Logo, ao adquirir caráter de norma supra legal, o Pacto de San José da Costa Rica inviabilizou qualquer hipótese de prisão civil prevista na legislação infraconstitucional, com exceção da prisão civil por dívida alimentar. 


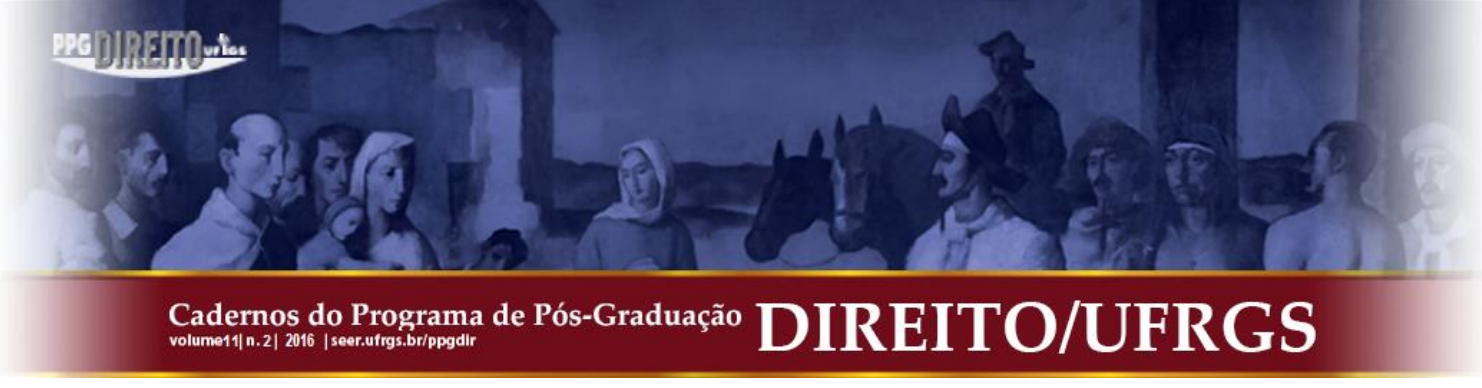

A par disso, a Terceira Câmara de Direito Civil do Tribunal de Justiça de Santa Catarina entendeu pela legalidade da prisão civil por inadimplemento voluntário e inescusável de obrigação alimentícia:

HABEAS CORPUS. EXECUÇÃO DE ALIMENTOS. PRISÃO CIVIL. INADIMPLÊNCIA VOLUNTÁRIA E INESCUSÁVEL. LEGALIDADE DO DECRETO PRISIONAL. CUMPRIMENTO DA PENA EM REGIME ABERTO. MEDIDA QUE NÃO SE COADUNA COM A FINALIDADE DA PRISÃO CIVIL. PRECEDENTES JURISPRUDENCIAIS. SEGREGAÇÃO IMPOSTA POR 90 (NOVENTA) DIAS. ART. 19 DA LEI N. 5.478/1968. ANTINOMIA DAS NORMAS. OBSERVÂNCIA DA LEGISLAÇÃO ESPECIAL. ILEGALIDADE EVIDENCIADA. LIMITAÇÃO EM 60 (SESSENTA) DIAS DE SEGREGAÇÃO. ORDEM PARCIALMENTE CONCEDIDA. (TJSC, Habeas Corpus n. 2012.046273-3, de Balneário Camboriú, rel. Des. Fernando Carioni, j. 14-08-2012). (SANTA CATARINA, 2012)

Ao julgar o referido recurso, o Tribunal de Justiça de Santa Catarina entendeu que a prisão civil do devedor de alimentos não é medida punitiva ou retributiva, mas uma forma de compelir o inadimplente a cumprir com a obrigação alimentar.

Nessa perspectiva, observa-se que o Superior Tribunal de Justiça consolidou entendimento no sentido da incorporação do Pacto de San José da Costa Rica ao ordenamento jurídico brasileiro com status de norma supra legal:

RECURSO EM HABEAS CORPUS. DEPOSITÁRIO INFIEL JUDICIAL. PRISÃO CIVIL. RECENTE MUDANÇA DO POSICIONAMENTO DO STF (HC N. 87.585/TO E RE N. 466.343/SP). PACTO DE SAN JOSÉ DA COSTA RICA. NORMA INCORPORADA AO ORDENAMENTO JURÍDICO BRASILEIRO COM STATUS SUPRALEGAL. DECORROGAÇÃO DAS NORMAS PRÉEXISTENTES QUE REGULAVAM A SITUAÇÃO DA PRISÃO CIVIL DO DEPOSITÁRIO INFIEL. 1. O Supremo Tribunal Federal consolidou entendimento no sentido de que a incorporação do Pacto de São José da Costa Rica ao ordenamento jurídico pátrio com status de norma supra legal restringiu a prisão civil por dívida ao descumprimento voluntário e inescusável de prestação alimentícia. Com isso, concluiu aquela Corte Suprema que os tratados internacionais de direitos humanos que tratam da matéria derrogam as normas infra-legais autorizadoras da custódia do depositário infiel. Tal entendimento foi acompanhado por esta Corte Superior. 2. Recurso ordinário provido. Decisão: a Turma, por unanimidade, deu provimento ao recurso ordinário, nos termos do voto do Sr. Ministro-Relator. (BRASIL, 2008).

Em função disso, verifica-se que, ao reconhecer o status de norma supra legal do Pacto de San José da Costa Rica, o Superior Tribunal de Justiça restringiu a prisão civil por dívida ao descumprimento voluntário e inescusável de prestação alimentícia. 


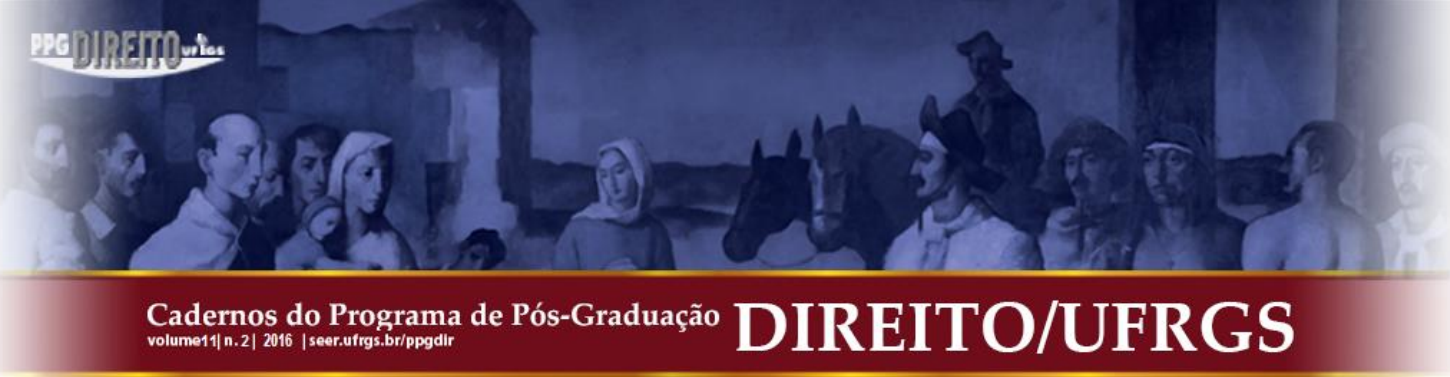

O Supremo Tribunal Federal, por sua vez, explica que a hierarquia intermediária de norma supra legal do Pacto de San José da Costa Rica afasta a regra ordinária brasileira que possibilita a prisão civil por dívida:

HABEAS CORPUS. SALVO-CONDUTO. PRISÃO CIVIL. DEPOSITÁRIO JUDICIAL. DÍVIDA DE CÁRATER NÃO ALIMENTAR. IMPOSSIBILIDADE. ORDEM CONCEDIDA. 1. O Plenário do Supremo Tribunal Federal firmou a orientação de que só é possível a prisão civil do "responsável pelo inadimplemento voluntário e inescusável de obrigação alimentícia" (inciso LXVII do art. $5^{\circ}$ da CF/88). Precedentes: HCs 87.585 e 92.566, da relatoria do ministro Marco Aurélio. 2. A norma que se extrai do inciso LXVII do artigo $5^{\circ}$ da Constituição Federal é de eficácia restringível. Pelo que as duas exceções nela contidas podem ser apontadas por lei, quebrantando, assim, a força protetora da proibição, como regra geral, da prisão civil por dívida. 3. O Pacto de San José da Costa Rica (ratificado pelo Brasil Decreto 678 de 6 de novembro de 1992), para valer como norma jurídica interna do Brasil, há de ter como fundamento de validade o $\S 2^{\circ}$ do artigo $5^{\circ}$ da Magna Carta. A se contrapor, então, a qualquer norma ordinária originalmente brasileira que preveja a prisão civil como dívida. Noutros termos: o Pacto de San José da Costa Rica, passando a ter como fundamento de validade o $\$ 2^{\circ}$ do art. $5^{\circ}$ da $\mathrm{CF} / 88$, prevalece como norma supra legal em nossa ordem jurídica interna e, assim, proíbe a prisão civil por dívida. Não é norma constitucional - à falta do rito exigido pelo $\S 3^{\circ}$ do artigo $5^{\circ}--$, mas a sua hierarquia intermediária de norma supra legal autoriza afastar regra ordinária brasileira que possibilite a prisão civil por dívida. 4 . No caso, o paciente corre o rico de ver contra si expedido mandado prisional por se encontrar na situação de infiel depositário judicial. 5. Ordem concedida. Decisão: a Turma deferiu o pedido de habeas corpus, nos termos do voto do Relator. Unânime. (BRASIL, 2009).

DEPOSITÁRIO INFIEL - PRISÃO. A subscrição pelo Brasil do Pacto de São José da Costa Rica, limitando a prisão civil por dívida ao descumprimento inescusável de prestação alimentícia, implicou a derrogação das normas estritamente legais referentes à prisão do depositário infiel. Decisão: o Tribunal, por votação unânime, concedeu a ordem de habeas corpus, nos temos do voto do Relator. (BRASIL, 2008).

Consequentemente, o Supremo Tribunal Federal entendeu que o Pacto de San José da Costa Rica prevalece como norma supra legal no ordenamento jurídico interno, implicando a derrogação das normas referentes à prisão do depositário infiel e limitando a prisão civil por dívida ao inadimplemento da obrigação alimentar.

Em 03 de dezembro de 2008, a Suprema Corte, definiu que é ilícita a prisão civil do depositário infiel, permanecendo apenas no ordenamento jurídico brasileiro a prisão civil do devedor de alimentos, acolhendo, desse modo, a tese da supra legalidade dos tratados internacionais de direitos humanos que não foram aprovados, conforme alteração trazida pela Emenda Constitucional no 45/2004 (SOUZA, 2010, p. 53).

Por tais razões, depreende-se que o Supremo Tribunal Federal elevou o Pacto de San José da Costa Rica ao status de norma supra legal, vedando expressamente a prisão do 


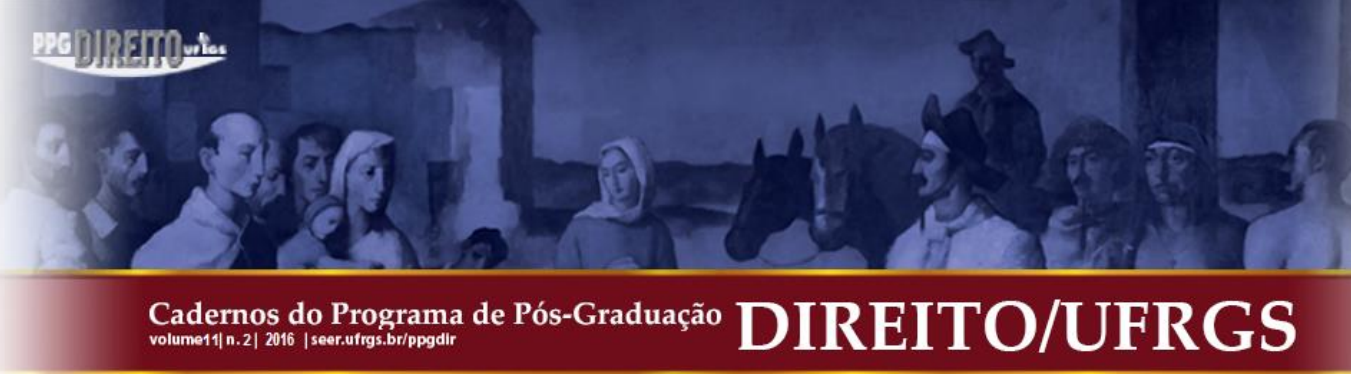

depositário infiel com a edição da Súmula Vinculante n. ${ }^{\circ}$ 25, subsistindo atualmente somente a prisão civil por inadimplemento inescusável de obrigação alimentar.

\section{CONSIDERAÇÕES FINAIS}

Diante do exposto, analisou-se o instituto dos alimentos na relação de parentesco, além de se verificar as hipóteses que ensejam a decretação da prisão civil, em decorrência do débito alimentar, demonstrando o cabimento desse instituto no ordenamento jurídico brasileiro.

A aplicação do instituto da prisão civil no ordenamento jurídico brasileiro se justifica em razão da ratificação pelo Brasil da Convenção Americana de Direitos Humanos, o Pacto de San José da Costa Rica, assinado em 25 de setembro de 1992, passando a vigorar para o país a partir dessa data.

Nota-se que o Pacto de San José da Costa Rica foi elevado no ordenamento jurídico brasileiro como status normativo, uma vez que o referido tratado veda a prisão civil por dívida, permitindo somente a prisão civil no caso de inadimplemento da obrigação alimentar.

Nota-se que este status normativo adquirido pela Convenção Americana de Direitos Humanos, o Pacto de San José da Costa Rica, retratou que a legislação brasileira é lacunosa quanto à norma que deve ser aplicada, em caso de um conflito entre as normas de Direito Internacional e a normas de Direito Interno, demonstrando que tal embate deve ser solucionado pela doutrina e pela jurisprudência, ficando ao encargo dela estabelecer qual a corrente doutrinária a ser aplicada.

Por fim, realizada uma análise jurisprudencial a respeito do status jurídico do Pacto de San José da Costa Rica, verificou-se, de acordo com o entendimento dos Tribunais Superiores, que a corrente adotada com relação ao status normativo no ordenamento jurídico brasileiro era a que sustentava a igualdade entre o Tratado e a Lei Federal, em que os tratados são considerados normas infraconstitucionais, os quais têm a mesma força normativa que as leis ordinárias, revogando-se as normas anteriores que com ela sejam incompatíveis.

Entretanto, o atual entendimento do Supremo Tribunal Federal e demais Tribunais inferiores é que os tratados internacionais que não forem aprovados com o quórum previsto no parágrafo $3^{\circ}$, do artigo $5^{\circ}$ da Constituição Federal terão caráter de norma supra legal, ou seja, estão hierarquicamente abaixo da Constituição Federal, mas acima da Legislação infraconstitucional, fazendo com que as Leis que previam e regulamentavam a prisão civil do 


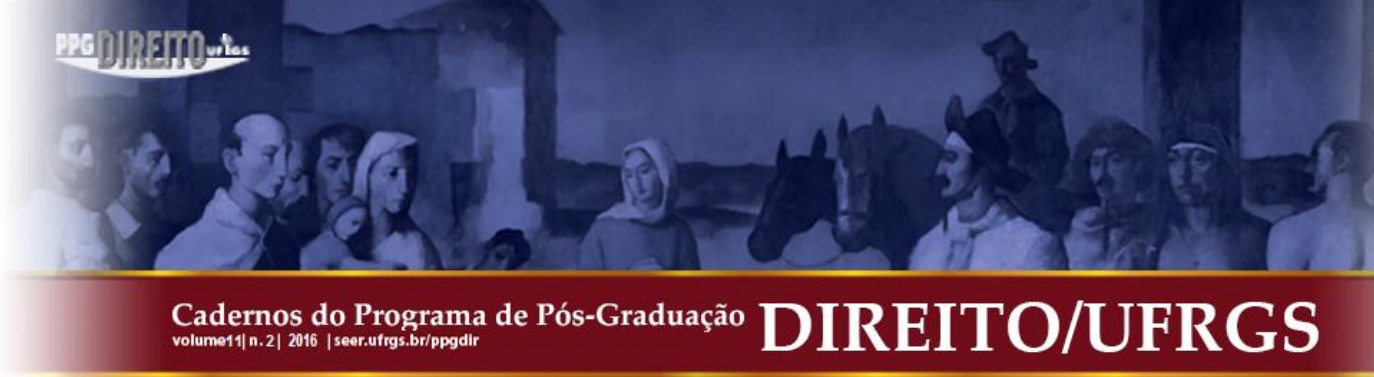

depositário infiel fossem revogadas, subsistindo somente a prisão civil do devedor de alimentos.

\section{REFERÊNCIAS}

ARIOSI, Mariangela de F. As relações entre o direito internacional e o direito interno. Disponível em: < http://www.egov.ufsc.br/portal/sites/default/files/anexos/21952-21953-1PB.htm>. Acesso em: 10 mar.2015.

ATHANÁSIO, Evanguelia Eugênia Gomes. A prisão civil por dívida alimentícia. Itajaí: Universidade do Vale do Itajaí, 2008. Disponível em: $<$ http://siaibib01.univali.br/pdf/Evanguelia\%20Eugenia\%20Gomes\%20Athanasio.pdf $>$. Acesso em: 09 mar. 2015.

BRASIL. Constituição da República Federativa do Brasil de 1988. Disponível em: $<$ http://www.planalto.gov.br/ccivil_03/constituicao/constitui\%C3\%A7ao.htm>. Acesso em: 15 mai. 2015.

Decreto $n^{0}$ 678, de 06 de novembro de 1992. Promulga a Convenção Americana sobre Direitos Humanos (Pacto de São José da Costa Rica), de 22 de novembro de 1969. Disponível em: < http://www.planalto.gov.br/ccivil_03/decreto/D0678.htm > . Acesso em: 07 mai. 2015.

. SUPREMO TRIBUNAL FEDERAL. Súmula Vinculante n. ${ }^{\circ}$ 25. Disponível em:

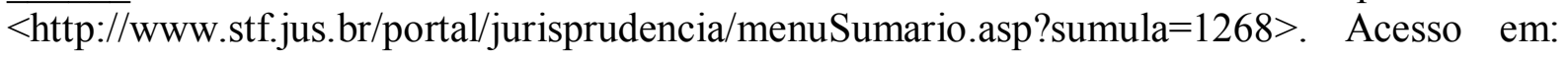
15 mai. 2015.

. Supremo Tribunal Federal. Habeas Corpus $n^{\circ} 87.585 /$ TO. Relator: Ministro Marco Aurélio. Brasília, 3 de dezembro de 2008. Disponível em: $<$ http://www.stf.jus.br/portal/jurisprudencia/visualizarEmenta.asp?s1 $=000000127 \&$ base $=$ base Acordaos>. Acesso em: 10 mai. 2015.

CAHALI, Yussef Said. Dos alimentos. 6. ed. São Paulo: Editora Revista dos Tribunais, 2009.

DIAS, Maria Berenice. Manual de direito das famílias. 5. ed. São Paulo: Editora Revista dos Tribunais, 2009. 


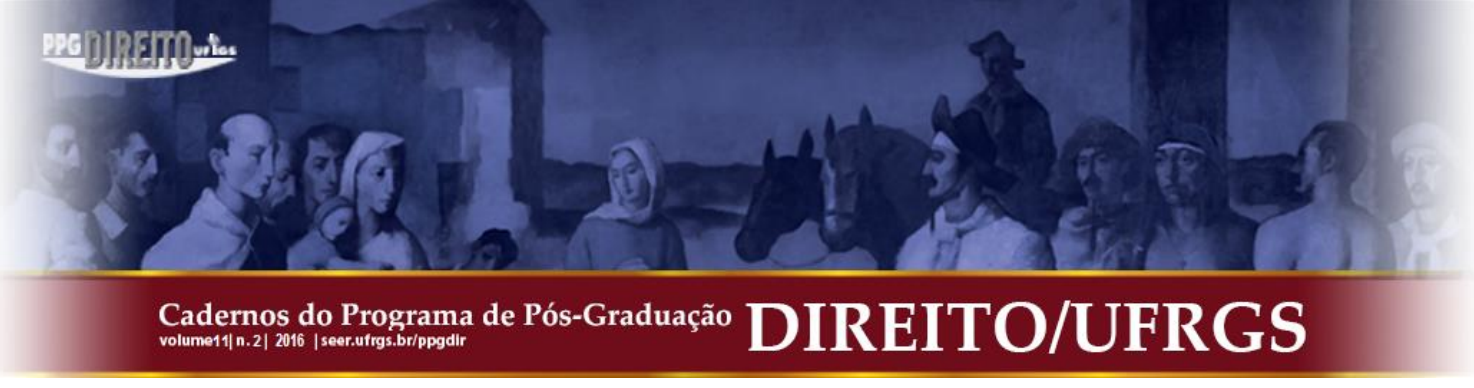

EMERIQUE, Lilian Balmant; GUERRA, Sidney. A incorporação dos tratados internacionais de direitos humanos na ordem jurídica brasileira. Brasília: Revista Jurídica. v. 10, n. 90, Edição Especial, abr./mai. 2008. Disponível em: $<$ http://www.planalto.gov.br/ccivil_03/revista/Rev_90/Artigos/PDF/SidneyGuerra_Rev90.pdf >. Acesso em: 09 mar.2015.

GONÇALVES, Carlos Roberto. Direito civil brasileiro: direito de família. 5. ed. São Paulo: Saraiva, 2005.

LINARD, Daniel Gurgel; ALCANTARA, Michele Alencar da Cruz. A Influência do Pacto de San José da costa rica no instituto da prisão civil do depositário infiel no Brasil. XIX Encontro Nacional do CONPEDI. Direito Internacional e Globalização. 2010. Florianópolis: BOITEUX, 2010.

LUCA, Guilherme Domingos; SANTOS JUNIOR, Danilo Rinaldi. Guarda compartilhada dos padrastos e madrastas: efetivação do princípio do maior interesse da criança e do adolescente. In: FERRAZ, Carolina Valença; OLIVEIRA, José Sebastião de; POLI, Luciana Costa (Orgs.). XXIII Congresso Nacional do CONPEDI. 1. ed. Florianópolis: CONPEDI, 2014.

MARINHO, Lívia Ribeiro Veronesi. O ingresso dos tratados no ordenamento jurídico brasileiro: a prisão civil do depositário infiel e a constitucionalidade do pacto de San José da costa rica. Rio de Janeiro: Pontifícia Universidade Católica do Rio de Janeiro, 2008. Disponível em: < http://www.maxwell.lambda.ele.puc-rio.br/12012/12012.PDF>. Acesso em: 22 mar. 2015.

MINAS GERAIS. Tribunal de Justiça de Minas Gerais. Agravo de instrumento $\mathrm{n}^{\circ}$ 1.00223.97.003817-8/002, da 17 Câmara Cível. Relator: Desembargador Eduardo Mariné da Cunha. Belo Horizonte, 5 de março de 2009. Disponível em: <http://www5.tjmg.jus.br>. Acesso em: 09 mar. de 2015.

PORTO, Sérgio Gilberto. Doutrina e Prática dos Alimentos. 4. ed. São Paulo: Editora Revista dos Tribunais, 2011.

RIBEIRO, Mikelli Marzzini Lucas Alves; AGUIAR FILHO, Valfredo de Andrade. Recepção dos tratados internacionais de direitos humanos no ordenamento pátrio e o novo entendimento do STF. Revista da Universidade Estadual da Paraíba. v. 1, n.1, 2009. Disponível em: $<$ http://revista.uepb.edu.br/index.php/datavenia/article/viewFile/509/289>. Acesso em: 08 mar. 2015. 


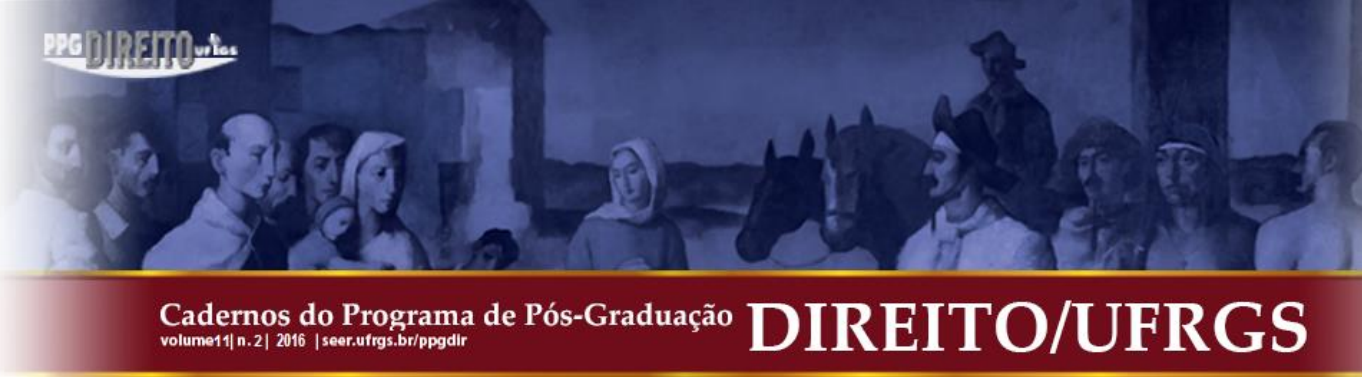

RIO GRANDE DO SUL. Tribunal de Justiça do Rio Grande do Sul. Habeas corpus $\mathrm{n}^{\mathrm{o}}$ 70044410975, da Décima Oitava Câmara Cível. Relator: Pedro Celso Dal Prá. Porto Alegre, 10 de agosto de 2011. Disponível em: $<$ http:// www1.tjrs.jus.br $>$. Acesso em: 11 de jun. 2014.

RIZZARDO, Arnaldo. Direito de família. 5. ed. Rio de Janeiro: Forense, 2007.

SANTA CATARINA. Tribunal de Justiça de Santa Catarina. Habeas corpus n ${ }^{\circ}$ 2007.0509891, da Primeira Câmara de Direito Comercial. Relator: Ricardo Fontes. Florianópolis, 8 de novembro de $2007 . \quad$ Disponível em: $<$ http://app.tjsc.jus.br/jurisprudencia/html.do?q=\&only_ementa=\&frase=\&id=AAAbmQAAB AAAJ5zAAD\&categoria=acordao $>$. Acesso em: 10 mar. 2015.

SANTOS JÚNIOR, Rubens Fernando Clamer dos. Pacto de são José da costa rica: análise da prisão civil do depositário infiel proveniente de execução trabalhista. Porto Alegre: Associação dos Magistrados da Justiça do Trabalho da IV Região, 2009. Disponível em: $<$ http://www.amatra4.org.br/publicacoes/cadernos/caderno-12?start=3>. Acesso em: 12 fev. 2015.

SOUZA, Gabriela Ribeiro de. A prisão civil no ordenamento jurídico brasileiro. Naviaraí: Universidade Estadual do Mato Grosso do Sul, 2010. Disponível em: $<$ http://www.uems.br/portal/biblioteca/repositorio/2011-07-14_10-55-58.pdf $>$. Acesso em: 07 mar. 2015.

VALENTIM, Daniela Rodrigues; MANDELLI JÚNIOR, Roberto Mendes. Convenção americana de direitos humanos. Grupo de Trabalho de Direitos Humanos, Procuradoria Geral do Estado. Direitos humanos: construção da liberdade e igualdade. São Paulo: Centro de Estudos, 2000.

Submissão: 30/03/2015

Aceito para Publicação: 11/06/2015 


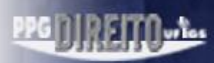

Cadernos do Programa de Pós-Graduação volume11| n. 2| 2016 | seer.ufrgs.br/ppgditr

DIREITO/UFRGS 